\title{
Implementation of Web-based Analytic Network Process for Highway Maintenance Planning
}

\author{
Noldy Sinsu \\ Department of Information \\ System \\ Diponegoro University \\ Semarang - Indonesia
}

\author{
Eko Sediyono \\ Department of Information \\ System \\ Satya Wacana Christian \\ University Salatiga - Indonesia
}

\author{
Aris Puji Widodo \\ Department of Informatics \\ Diponegoro University \\ Semarang - Indonesia
}

\begin{abstract}
The Maintenance of highway as an important role in the reliability of the conditions can be affected positively the economic sector, government, and society. which will be the priority of highway maintenance planning is to pay attention to the supporting parameters standards that affect the highways segment. These parameters as a variable in Analytic Network Process method. In this research, the first step is to identify problems, data collection, form parameters, data processing parameters before to the next step of the ranking process. After grouping the highway segment, the next step is assessing its highway segment using Analytic Network Process (ANP) method. The results of the ranking process are stored into the database and then represented by displaying the graphs and tables. The final result of the information shows the rankings 27 highways and the result of the accuracy of $80 \%$ of the system results. And field data that are shown from one national highway and five provincial highways. From the test results, the system is able to provide information about highway maintenance that will be a priority ranking which one the top list that needed to be maintenance.
\end{abstract}

\section{General Terms}

Method Analytic Network Process

\section{Keywords}

Analytic Network Process (ANP), Maintenance, Highway, Web-Based and ANP

\section{INTRODUCTION}

The availability and the reliability of highway conditions will positively affect the economic sector, government, and society. The highways have an important role in realizing the national development so that people need the comfort and smoothness of highway facilities in carrying out daily activities [1]. There is the close relationship between highways transport and economic development because strong economics foundation provides stabilization in highway transport demand and also affects the economic development. An adequate highway can provide the comforts for its users. many highways are unrecognizable because of the absence the construction or the regular maintenance [2]. Therefore, it is necessary to excellent handlings, such as highways maintenance or highways improvement, it is intended that the highway conditions will be in accordance with the planned age of highways [5].

ANP methods have been widely used for various qualitative studies, such as decision making, forecasting, strategizing, mapping, evaluations, resource allocation and so on. To assist decision-makers in evaluation and synthesis any number of factors in the hierarchy or network [4], in general in prioritizing decision problems using a network approach without setting the level [3]. As a multi criteria decision- maker with a decision-making approach appropriately related to the selection of transport infrastructure projects [7], the overall risk priority of the project supply network is to initiate a timely mitigation strategy against the cost consequences and the timing significance of the risk of major project performance steps [10].

In this study, the focus of the problem is maintaining the highway. This is because of the highway as a media that liaison one and another location and the highway maintenance process needed some criteria that must be considered to the smoothness of the highway maintenance itself, ie, highway conditions, volumes traffic, economics and land use. Minister of Public Works adopted the government regulation [5]. The scope of arrangements in ministerial regulations includes technical requirements and maintenance technical criteria of highway that applied to the national highways, provincial highways, district highways, and the urban highways [5]. The study was conducted using the ANP method to determine road maintenance based on roadside ranking results against its criteria [6], [7], and using a web-based system to facilitate access intended to provide information on road projects in detail, informative and accessible by the community [11], the web-based system is also used to categorize and analyze incident addressing [11], the web-based system facilitates online access, image visualization, and analysis, as well as additional data and maps [13]. The researcher chose ANP as a multi criteria ranking method, therefore assumption and justification theories based on assumptions, and can assist decision-making involving multiple decision makers [8], [9]. The main criterion will require the adoption of multi criteria of decision making so that it can provide a reference for planning the maintenance of Semarang City highway for the future.

\section{METHODOLOGY}

\subsection{Data Collection}

In this research, the data that used is field data obtained from the office of the highway of Central Java, the questionnaire result and interview result about influencing of criteria against to the road maintenance planning. The criteria that used according to Regulation of Minister of Public Works No.13/2011 (PMPU 2011). The proposed system framework starts from the input data is highway data (data list of highway, data of highway conditions, traffics volume data, economic data, and land use data) which is then performed by expert assessment of the proposed criteria (15 criteria)). The data on the results of the experts processed by the method of Analytic Network Process (ANP) that proposed for more detail can be seen in Figure 1. The final result is the ranking information of prioritization of highway maintenance and all highways ranking. 
The data that used is data obtained from 27 roads, which is spread into 6 national road segments and 21 provincial road segments in Semarang city.

Data criteria were taken 27 roads segment (Table 1 and Table 2 ), the criteria as follows:

[1] Road condition consisting of C1 is a good road, C2 is a medium road, C3 is a damaged road, C4 is a heavy damaged road,
[2] traffic volume consisting of $\mathrm{C} 5$ is a lightweight truck, C6 is a medium truck, C7 is a heavy truck, C8 is BUS, C9 is a car, C10 is a motorcycle,

[3] C11 is the economy (road maintenance fund),

Land use consisting of $\mathrm{C} 12$ is agriculture, $\mathrm{C} 13$ is education field, $\mathrm{C} 14$ is the socio-cultural, C15 is trade and service.

Table 1. Data parameter 27 highways

\begin{tabular}{|c|c|c|c|c|c|c|c|c|c|}
\hline \multirow{2}{*}{ Roads Name } & \multicolumn{9}{|c|}{ Criteria } \\
\hline & C1 & $\mathbf{C 2}$ & $\mathbf{C 3}$ & $\mathbf{C 4}$ & C5 & C6 & C7 & C8 & C9 \\
\hline Jl. Cangkiran - ungaran bts.kodya & 10,202 & 13 & 1 & 0 & 713 & 474 & 0 & 752 & 371 \\
\hline J1. Pandanaran & 216 & 2 & 300 & 0 & 360 & 27 & 0 & 25,250 & 126 \\
\hline Jl. Bunderan simpang lima & 100 & 1,047 & 100 & 0 & 391 & 10 & 0 & 70,406 & 232 \\
\hline J1. A. Yani & 60 & 600 & 200 & 0 & 88 & 0 & 0 & 23,435 & 128 \\
\hline Jl. Brigjend katamso & 0 & 480 & 0 & 0 & 184 & 26 & 0 & 18,966 & 249 \\
\hline Jl. Brigjend sudiarto & 300 & 92 & 800 & 0 & 1,380 & 442 & 0 & 34,984 & 556 \\
\hline Jl. Anton sujarwo & 2 & 4 & 0 & 0 & 3,282 & 2,263 & 7 & 2,027 & 1,554 \\
\hline Jl. Setia budhi & 3 & 700 & 200 & 0 & 1,528 & 3,393 & 618 & 3,548 & 4,749 \\
\hline Jl. Teuku umar & 540 & 400 & 0 & 0 & 1,641 & 3,879 & 68 & 4,793 & 3,189 \\
\hline Jl. Dr. Wahidin & 2 & 440 & 0 & 0 & 2,928 & 1,400 & 52 & 1,023 & 734 \\
\hline J1. Mt. Haryono & 875 & 0 & 0 & 0 & 2,459 & 944 & 16 & 691 & 762 \\
\hline Jl. Kompol maksum & 400 & 240 & 0 & 0 & 1,701 & 657 & 23 & 870 & 662 \\
\hline Jl. Dr. Cipto & 3 & 310 & 0 & 0 & 880 & 554 & 43 & 534 & 338 \\
\hline Jl. Widoharjo & 0 & 400 & 0 & 0 & 2,895 & 2,617 & 38 & 2,195 & 2,170 \\
\hline Jl. Raden patah & 110 & 1 & 0 & 0 & 3,252 & 2,683 & 2 & 828 & 2,175 \\
\hline Jl. Kaligawe & 600 & 5 & 517 & 0 & 3,610 & 1,640 & 5 & 430 & 1,299 \\
\hline Jl. Usman janatin & 100 & 1 & 100 & 0 & 8,873 & 6,477 & 339 & 1,406 & 3,127 \\
\hline Jl. Arteri utara (martadinata,fly over,yos sudarso) & 7 & 8 & 430 & 100 & 4,552 & 2,573 & 384 & 2,526 & 976 \\
\hline J1. Tugu muda & 100 & 200 & 0 & 0 & 4,588 & 2,274 & 84 & 2,117 & 1,680 \\
\hline Jl. Dr. Sutomo & 1 & 200 & 0 & 0 & 4,602 & 2,406 & 44 & 2,207 & 2,011 \\
\hline Jl. S. Parman & 2 & 670 & 0 & 0 & 6,038 & 3,099 & 5 & 1,576 & 2,094 \\
\hline Jl. Sultan agung & 1,385 & 500 & 0 & 0 & 3,837 & 1,279 & 19 & 492 & 1,123 \\
\hline Jl. Mgr. Sugiyopranoto & 830 & 100 & 0 & 0 & 7,177 & 3,390 & 21 & 2,923 & 1,941 \\
\hline Jl. Jendral sudirman & 1 & 700 & 0 & 0 & 7,350 & 3,140 & 26 & 2,407 & 1,948 \\
\hline Jl. Siliwangi & 200 & 1,565 & 800 & 0 & 5,589 & 2,765 & 20 & 865 & 2,021 \\
\hline Jl. Walisongo & 1 & 5,915 & 2 & 100 & 5,712 & 3,197 & 18 & 1,837 & 2,328 \\
\hline Bts. Kota kendal - bts. Kota semarang & 4 & 4,138 & 1 & 100 & 5,450 & 3,624 & 81 & 2,949 & 3,046 \\
\hline
\end{tabular}

* Source: Office of Public Works-Human Settlements and Spatial Planning of Central Java

Table 2. (Continued)

\begin{tabular}{|c|c|c|c|c|c|c|}
\hline \multirow{2}{*}{ Roads Name } & \multicolumn{6}{|c|}{ Criteria } \\
\hline & $\mathbf{C 1 0}$ & C11 & $\mathbf{C 1 2}$ & $\mathbf{C 1 3}$ & C14 & C15 \\
\hline Jl. Cangkiran - ungaran bts.kodya & 7,847 & $16,750,000,118$ & 10 & 20 & 0 & 30 \\
\hline J1. Pandanaran & 62,877 & $9,504,451,000$ & 8 & 15 & 4 & 50 \\
\hline
\end{tabular}




\begin{tabular}{|c|c|c|c|c|c|c|}
\hline \multirow{2}{*}{ Roads Name } & \multicolumn{6}{|l|}{ Criteria } \\
\hline & $\mathbf{C 1 0}$ & C11 & $\mathrm{C12}$ & $\mathbf{C 1 3}$ & C14 & C15 \\
\hline Jl. Bunderan simpang lima & 124,526 & $2,065,858,000$ & 23 & 11 & 7 & 40 \\
\hline J1. A. Yani & 67,967 & $3,065,858,000$ & 12 & 20 & 8 & 35 \\
\hline Jl. Brigjend katamso & 55,887 & $2,340,000,000$ & 10 & 60 & 10 & 27 \\
\hline Jl. Brigjend sudiarto & 79,003 & $2,340,000,000$ & 9 & 30 & 7 & 20 \\
\hline Jl. Anton sujarwo & 487 & $4,110,707,000$ & 30 & 35 & 0 & 25 \\
\hline Jl. Setia budhi & 2,432 & $4,913,772,000$ & 25 & 27 & 20 & 20 \\
\hline Jl. Teuku umar & 1,862 & $9,000,028,000$ & 10 & 20 & 15 & 35 \\
\hline Jl. Dr. Wahidin & 766 & $4,636,500,000$ & 8 & 25 & 17 & 25 \\
\hline Jl. Mt. Haryono & 963 & $4,122,705,000$ & 9 & 19 & 0 & 0 \\
\hline Jl. Kompol maksum & 342 & $4,701,513,000$ & 20 & 20 & 18 & 30 \\
\hline Jl. Dr. Cipto & 368 & $4,689,641,000$ & 60 & 10 & 16 & 35 \\
\hline Jl. Widoharjo & 874 & $8,800,023,000$ & 30 & 11 & 25 & 27 \\
\hline Jl. Raden patah & 372 & $4,748,883,000$ & 35 & 15 & 20 & 20 \\
\hline Jl. Kaligawe & 148 & $7,215,030,000$ & 27 & 20 & 28 & 17 \\
\hline Jl. Usman janatin & 1,903 & $8,130,599,000$ & 20 & 27 & 15 & 14 \\
\hline Jl. Arteri utara (martadinata,fly over,yos sudarso) & 64 & $4,642,960,000$ & 17 & 30 & 0 & 15 \\
\hline Jl. Tugu muda & 763 & $4,501,894,000$ & 14 & 20 & 10 & 10 \\
\hline Jl. Dr. Sutomo & 1,958 & $1,730,730,000$ & 15 & 9 & 25 & 11 \\
\hline Jl. S. Parman & 1,155 & $1,734,241,000$ & 20 & 30 & 20 & 0 \\
\hline Jl. Sultan agung & 172 & $4,714,330,000$ & 27 & 25 & 8 & 30 \\
\hline Jl. Mgr. Sugiyopranoto & 625 & $4,793,957,000$ & 30 & 10 & 10 & 25 \\
\hline Jl. Jendral sudirman & 597 & $6,174,118,000$ & 20 & 8 & 0 & 10 \\
\hline Jl. Siliwangi & 500 & $3,900,898,000$ & 25 & 15 & 15 & 25 \\
\hline Jl. Walisongo & 174 & $5,411,511,000$ & 30 & 20 & 20 & 0 \\
\hline Bts. Kota kendal - bts. Kota semarang & 1,428 & $7,106,814,000$ & 40 & 21 & 0 & 10 \\
\hline
\end{tabular}

* Source: Office of Public Works-Human Settlements and Spatial Planning of Central Java

\subsection{Research Step}

The research steps are problem identification, data collection, parameter formation, and data processing parameters. Data modeling is a step that must be completed first before doing the next process, which needs to be considered in the data modeling step is the classification of data that has been collected into criteria for the ANP process.

The next step is coding PHP programming language with the steps as follows:

a) Develop problem structures and develop linkage models Criteria control, and determine alternative options. If there are elements that have the equivalent quality then grouped into a similar component.

b) Forming pairwise comparison matrix

ANP assumes that the decision maker must make a comparison of interests between all elements for each level in pairs. The comparison is transformed into the matrix form A. Value $\alpha_{\mathrm{ij}}$ represents the relative importance value of the element on the line to $-i$ against the elements in the column to $-j$. for example $\alpha_{i j}=\frac{w i}{w j}$. If any $n$ elements are compared, then the comparison matrix A is defined as: 


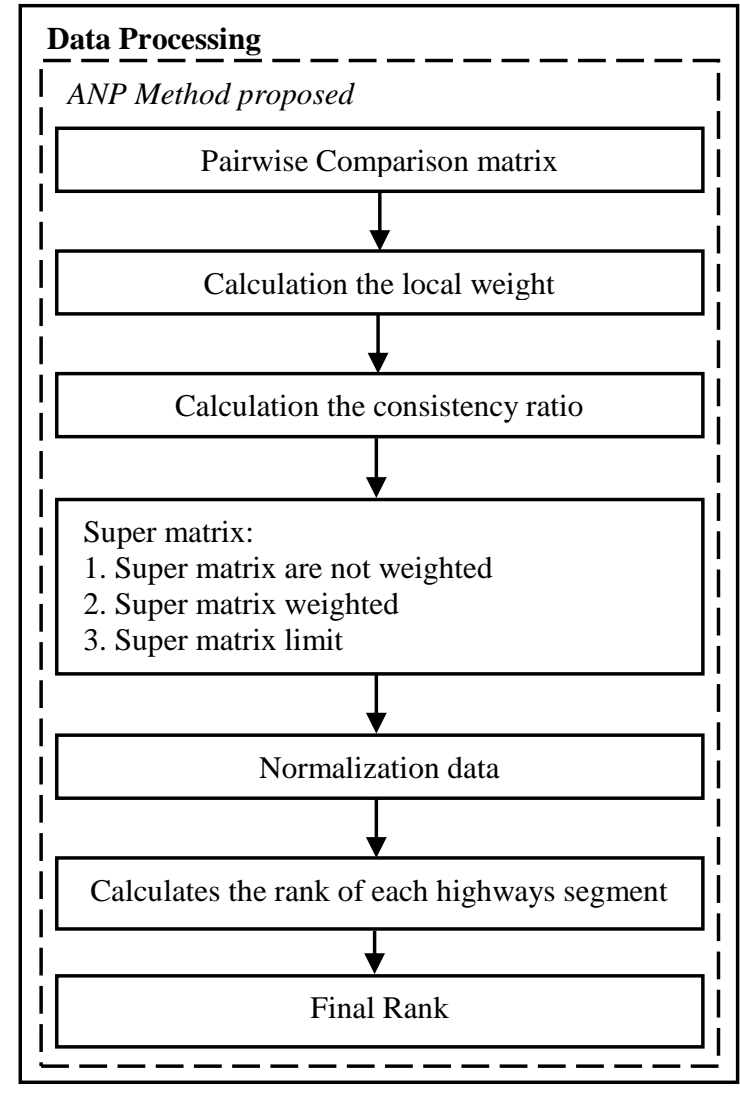

Fig 1. ANP Method that proposal

$=\left[\begin{array}{cccc}\frac{w_{1}}{w_{1}} & \frac{w_{1}}{w_{2}} & \cdots & \frac{w_{1}}{w_{n}} \\ \frac{w_{2}}{w_{1}} & \frac{w_{2}}{w_{2}} & \cdots & \frac{w_{2}}{w_{n}} \\ \vdots & \cdots & \cdots & \vdots \\ \frac{w_{n}}{w_{1}} & \frac{w_{n}}{w_{2}} & \cdots & \frac{w_{n}}{w_{2}}\end{array}\right]=\left[\begin{array}{cccc}1 & \alpha_{12} & \cdots & \alpha_{1 n} \\ \alpha_{21} & 1 & \cdots & \alpha_{2 n} \\ \vdots & \cdots & \cdots & \vdots \\ \alpha_{n 1} & \alpha_{n 2} & \cdots & 1\end{array}\right]$

c) Calculates the element weights

If pairwise comparisons are complete, the priority vector $\mathrm{w}$ referred to as the eigenvector is calculated by. Where A is a pairwise comparison matrix, $\mathrm{w}$ is an eigenvector, and $\lambda_{\text {maks }}$ is the largest eigenvalue of $\mathrm{A}$.

The eigenvector is the priority weight of a matrix which is then used in the preparation of super matrix.

$$
\mathrm{A} \cdot \mathrm{w}=\lambda_{\text {maks }} \cdot \mathrm{W}
$$

d) Calculates the consistency ratio

Consistency has two meanings, the first is similar objects can be grouped according to uniformity and relevance. Second, it concerns the level of relationship between objects based on certain criteria. In making decisions, it is important to know how good the consistency is. Therefore it is necessary to check the value of consistency by using a random index list (RI) which can be seen in Table 2 . Consistency ratio should be worth 10 percent or less. If the value is more than 10 percent, then the assessment of decision data should be corrected. In practice, such consistency is not possible. In the consistency matrix, practically $\lambda_{\text {maks }}=n$, whereas in the matrix, not every variation of $\mathrm{W}_{\mathrm{ij}}$ will bring changes to the value $\lambda_{\text {maks }}$. Deviation $\lambda_{\text {maks }}$ from $n$ is a consistency index parameter as follows.

$\mathrm{CI}=\frac{\lambda_{\text {maks }}-\mathrm{n}}{\mathrm{n}-1}$
Where CI is the consistency index, $\lambda_{\text {maks }}$ is the value eigen greatest, and $n$ is the number of elements that are compared. By comparing CI and RI there is a benchmark for determining the consistency level of a matrix, called the Consistency Ratio (CR). To calculate the consistency ratio is used the following equation.

$\mathrm{CR}=\frac{\mathrm{CI}}{\mathrm{RI}}$

Where CR is the consistency ratio, CI is the consistency index, and RI is the random index. Table 3 . shows the size of the matrix and the random index value that can be used as a benchmark to determine the consistency level of a matrix [7].

Table 3. Random Index Value

\begin{tabular}{|c|c|}
\hline Matrix Size & Value \\
\hline 1 & 0 \\
\hline 2 & 0 \\
\hline 3 & 0.5247 \\
\hline 4 & 0.8816 \\
\hline 5 & 1.1086 \\
\hline 6 & 1.2479 \\
\hline 7 & 1.3417 \\
\hline 8 & 1.4057 \\
\hline 9 & 1.4499 \\
\hline 10 & 1.4854 \\
\hline 11 & 1.514 \\
\hline 12 & 1.5365 \\
\hline 13 & 1.5551 \\
\hline 14 & 1.5713 \\
\hline 15 & 1.5838 \\
\hline 16 & 1.5978 \\
\hline 17 & 1.6086 \\
\hline 18 & 1.6181 \\
\hline 19 & 1.6265 \\
\hline 20 & 1.6341 \\
\hline 21 & 1.6409 \\
\hline 22 & 1.647 \\
\hline 23 & 1.6526 \\
\hline 24 & 1.6577 \\
\hline 25 & 1.6624 \\
\hline 26 & 1.6667 \\
\hline 27 & 1.6706 \\
\hline 28 & 1.6743 \\
\hline 29 & 1.6777 \\
\hline 30 & 1.6809 \\
\hline
\end{tabular}


If the value of $\mathrm{CR}=0$ then a comparison matrix can be said to be consistent if $\mathrm{CR} \leq 0.1$ then the matrix is quite consistent, and if $C R>0.1$ then it is said to be very inconsistent [6].

e) Making Supermatrix

Super matrix are the result of eigenvectors of a pairwise comparison matrix between clusters, criteria, and alternatives. Assuming a system has an $\mathrm{N}$ cluster in which elements in each cluster interact or have an effect on some or all of the existing clusters. If the cluster is denoted with ch where $h=1,2, \ldots, N$ with as many elements denoted as $\mathrm{e}_{\mathrm{h} 1}, \mathrm{e}_{\mathrm{h} 2}, \ldots, \mathrm{e}_{\mathrm{hn}_{\mathrm{h}}}$. The effect of one element in a cluster on another element in a system can be recipe toned by a ratio-scale eigenvector taken from a pairwise comparison matrix.

f) The final stage of the ANP method in which the rank of each criterion is obtained by calculating the final weight of each criterion. There are three kinds of weights that will be calculated that is raw weight, normal weight, and weight idea. The raw weight will be calculated by summing every normalized line of super matrix limit, while the normal weight is calculated by dividing the highest value by the number of criteria. So that the ideal weight hung by dividing the value of the normal weight with the highest value of the normal weight, then we get the highest weight of the ideal weight of one (1).

\section{RESULT AND ANALYSIS}

To achieve the research objectives discussed earlier, there are several steps that must be done. The stages are divided into several processes including, evaluation criteria that are part of data modeling to determine criteria to be used in ANP, comparisons of pairwise comparisons between criteria form the criteria matrix, data normalization, eigenvalue calculation, calculation of largest eigenvalue ( $\left.\lambda_{\text {maks }}\right)$, testing consistency ratio, super matrix calculation, and ranking.

\subsection{Application of Analytical Network Process}

The process of applying the ANP is the weighting of the 15 criteria used to calculate the matrix of pairwise comparisons, data normalization, the calculation of eigenvalues, the calculation of the largest eigenvalues $\left(\lambda_{\text {maks }}\right)$, the consistency ratio test, and the super matrix calculations (unweighted super matrix, super matrix weighted, and super matrix limits) determination of raw weights, normal weight and ideal weight of each priority road segment.

The final step of applying ANP method is to determine the rank of each segment by calculating the final weight of each criterion. Where the weight to be used in the calculation process consists of raw weights, normal weight, and ideal weight. For calculation of raw weights done by summing every line of normalized super matrix limit. Furthermore, in calculating the normal weight is done by dividing the value of the raw weights by the number of criteria. Then the calculation of the ideal weight is calculated by dividing the normal weight value with the highest value of the normal weight so that the highest value of the ideal weight $=1$. The roads segment that gets the value $=1$ on the ideal weight is the roads segment that will be a priority in maintenance planning. The ranking results are shown in Table 4.
Table 4. Result of final 27 roads segment

\begin{tabular}{|c|c|c|c|c|}
\hline No & Roads Name & Weight & $\begin{array}{l}\text { Ran } \\
\text { king }\end{array}$ & $\begin{array}{l}\text { Precenta } \\
\text { ge }(\%)\end{array}$ \\
\hline 1 & Jl. Usaman janatin & 0.033 & 1 & $3.25 \%$ \\
\hline 2 & Jl. Brigjend sudiarto & 0.031 & 2 & $3.13 \%$ \\
\hline 3 & $\begin{array}{l}\text { Jl. Bunderan } \\
\text { simpang lima }\end{array}$ & 0.031 & 3 & $3.13 \%$ \\
\hline 4 & Jl. A. Yani & 0.031 & 4 & $3.13 \%$ \\
\hline 5 & Jl. Pandanaran & 0.028 & 5 & $2.84 \%$ \\
\hline 6 & J1. Brigjend katamso & 0.026 & 6 & $2.55 \%$ \\
\hline 7 & $\begin{array}{l}\text { Jl. Arteri utara ( } \\
\text { martadinata, fly } \\
\text { over, } \\
\text { sudarso) }\end{array}$ & 0.026 & 7 & $2.55 \%$ \\
\hline 8 & $\begin{array}{l}\text { Bts. Kota kendal - } \\
\text { bts. Kota semarang }\end{array}$ & 0.023 & 8 & $2.30 \%$ \\
\hline 9 & Jl. Walisongo & 0.023 & 9 & $2.25 \%$ \\
\hline 10 & $\begin{array}{l}\text { Jl. Mgr. } \\
\text { Sugiyopranoto }\end{array}$ & 0.022 & 10 & $2.21 \%$ \\
\hline 11 & J1. Siliwangi & 0.021 & 11 & $2.08 \%$ \\
\hline 12 & Jl. Kaligawe & 0.019 & 12 & $1.90 \%$ \\
\hline 13 & Jl. Setia budhi & 0.019 & 13 & $1.89 \%$ \\
\hline 14 & Jl. S. Parman & 0.019 & 14 & $1.88 \%$ \\
\hline 15 & Jl. Jendral sudirman & 0.018 & 15 & $1.83 \%$ \\
\hline 16 & $\begin{array}{l}\text { Jl. Cangkiran } \\
\text { ungaran bts.kodya }\end{array}$ & 0.018 & 16 & $1.81 \%$ \\
\hline 17 & Jl. Sultan agung & 0.017 & 17 & $1.71 \%$ \\
\hline 18 & Jl. Teuku umar & 0.017 & 18 & $1.71 \%$ \\
\hline 19 & Jl. Tugu muda & 0.017 & 19 & $1.71 \%$ \\
\hline 20 & Jl. Kompol maksum & 0.017 & 20 & $1.71 \%$ \\
\hline 21 & Jl. Raden patah & 0.015 & 21 & $1.54 \%$ \\
\hline 22 & Jl. Dr. Wahidin & 0.015 & 22 & $1.53 \%$ \\
\hline 23 & Jl. Dr. Cipto & 0.015 & 23 & $1.53 \%$ \\
\hline 24 & Jl. Dr. Sutomo & 0.015 & 24 & $1.50 \%$ \\
\hline 25 & Jl. Widoharjo & 0.015 & 25 & $1.50 \%$ \\
\hline 26 & Jl. Mt. Haryono & 0.012 & 26 & $1.22 \%$ \\
\hline 27 & Jl. Anton sujarwo & 0.012 & 27 & $1.18 \%$ \\
\hline
\end{tabular}

Based on the calculation obtained the highest weight is 0.0325 , as well as the ideal value $=1$ with the percentage of $3.25 \%$ located on the Jl. Usman janatin. And the weight of the lowest value is 0.0118 , and the ideal value $=0.3631$ with the percentage of $1.18 \%$ located on the Jl. Anton sujarwo. The graph results are shown in Figure 2.

\subsection{Analysis of Accuracy}

Accuracy analysis is done to get the level of accuracy, the way is calculating the number of the appropriateness of alternative rankings of road segments that generated by the 
system based on real data. The process of calculating the accuracy test is determined using the accuracy equation.

$$
\text { Accuracy }(\%)=\frac{\sum \text { correct test data }}{\sum \text { total test data }} \times 100 \%
$$

Comparison of system rankings and rankings on real data is shown in Table 5.

Table 5. Accuracy system results

\begin{tabular}{|l|l|l|l|}
\hline No & System Results & $\begin{array}{l}\text { Data From } \\
\text { Minister of } \\
\text { Public Works }\end{array}$ & Information \\
\hline 1 & $\begin{array}{l}\text { Jl. Bunderan } \\
\text { simpang lima }\end{array}$ & $\begin{array}{l}\text { Jl. Bunderan } \\
\text { simpang lima }\end{array}$ & Suitable \\
\hline 2 & Jl. A. Yani & $\begin{array}{l}\text { Jl. Brigjend } \\
\text { Katamso }\end{array}$ & Unsuitable \\
\hline 3 & $\begin{array}{l}\text { Jl. Brigjend } \\
\text { Sudiarto }\end{array}$ & $\begin{array}{l}\text { Jl. Brigjend } \\
\text { Sudiarto }\end{array}$ & Suitable \\
\hline 4 & Jl. Pandanaran & Jl. Pandanaran & Suitable \\
\hline 5 & $\begin{array}{l}\text { Jl. Katamso Brigjend } \\
\text { Kand. Aani }\end{array}$ & Unsuitable \\
\hline 6 & $\begin{array}{l}\text { Jl.Cangkringan- } \\
\text { unggaran bts.kodya }\end{array}$ & $\begin{array}{l}\text { Jl.Cangkringan- } \\
\text { unggaran } \\
\text { bts.kodya }\end{array}$ & Suitable \\
\hline 7 & Jl. Setia budi & Jl. Setia budi & Suitable \\
\hline
\end{tabular}

\begin{tabular}{|l|l|l|l|}
\hline 8 & Jl. Mt. Haryono & Jl. Dr. Sutomo & Unsuitable \\
\hline 9 & Jl. Dr. Cipto & Jl. Dr. Cipto & Suitable \\
\hline 10 & Jl. Tugu muda & Jl. Tugu muda & Suitable \\
\hline 11 & Jl. Dr. Sutomo & Jl. Mt. Haryono & Unsuitable \\
\hline 12 & Jl. Usman janatin & $\begin{array}{l}\text { Jl. Unan } \\
\text { janatin }\end{array}$ & Suitable \\
\hline 13 & Jl. S. Parman & Jl. S. Parman & Suitable \\
\hline 14 & Jl. Siliwangi & Jl. Siliwangi & Suitable \\
\hline 15 & Jl. Walisongo & Jl. Walisongo & Suitable \\
\hline 16 & Jl. Dr. Wahidin & Jl. Dr. Wahidin & Suitable \\
\hline 17 & Jl. Sultan agung & Jl. Sultan agung & Suitable \\
\hline 18 & $\begin{array}{l}\text { Jl. Mgr. } \\
\text { Sugiyopranoto }\end{array}$ & $\begin{array}{l}\text { Jl. Sugiyopranoto } \\
\text { Suitable }\end{array}$ \\
\hline 19 & Jl. Jendral sudirman & $\begin{array}{l}\text { Jl. Jendral } \\
\text { sudirman }\end{array}$ & Suitable \\
\hline 20 & Jl. Anton sujarwo & $\begin{array}{l}\text { Jl. Anton } \\
\text { sujarwo }\end{array}$ & Suitable \\
\hline
\end{tabular}

Based on Table 5. It can be seen that from 6 provincial roads there are 3 road segments that become the priority of maintenance, the test of accuracy as follows:

$$
\text { Accuracy }(\%)=\frac{16}{20} \times 100 \%=80 \%
$$

\footnotetext{
Jl. Anton sujarwo $(0.0118,1.18 \%)$

Jl. Mt. Haryono $(0.0122,1.22 \%)$

Jl. Widoharjo $(0.015,1.5 \%)$
}

Jl. Dr. Sutomo $(0.015,1.5 \%)$

Jl. Dr. Cipto $(0.0153,1.53 \%)$

Jl. Dr. Wahidin $(0.0153,1.53 \%)$

Jl. Raden patah (0.0154, 1.54\%)

Jl. Kompol maksum $(0.0171$

$1.71 \%)$

Jl. Tugu muda $(0.0171,1.71 \%)$

Jl. Teuku umar $(0.0171,1.71 \%)$

Jl. Sultan agung $(0.0171,1.71 \%)$

Jl. Cangkiran - ungaran bts.kodya $(0.0181,1.81 \%)$

Jl. Jendral sudirman $(0.0183$, $1.83 \%)$

Jl. S. Parman $(0.0188,1.88 \%)$

Jl. Setia budhi $(0.0189,1.89 \%)$

Jl. Kaligawe $(0.019,1.9 \%)$

Jl. Siliwangi $(0.0208,2.08 \%)$
Jl. Usman janatin $(0.0325,3.25 \%)$

Jl. Brigjend sudiarto $(0.0313$ $3.13 \%$ )

- Jl. Bunderan simpang lima $(0.0313,3.13 \%)$

Jl. A. Yani $(0.0313,3.13 \%)$

Jl. Pandanaran $(0.0284,2.84 \%)$

Jl. Brigjend katamso $(0.0255$,

$2.55 \%)$

Jl. Arteri utara (martadinata, fly over,yos sudarso) $(0.0255,2.55 \%)$

Bts. Kota kendal - bts. Kota

semarang $(0.023,2.3 \%)$

Jl. Walisongo $(0.0225,2.25 \%)$

Jl. Mgr. Sugiyopranoto $(0.0221$, $2.21 \%$ )

Fig 2. The graph result

The result of the analysis has calculated the percentage of accuracy level indicating that the system built using ANP method has an accuracy level of $80 \%$ which means either based on priority ranking between field data and system output. The resulting rating system uses the ANP method by considering the 15 criteria $\left(\mathrm{C}_{1}-\mathrm{C}_{15}\right)$, the weight of each criterion, and the calculation of super matrix. From the test results obtained that the system designed by combining ANP and web-based methods can be applied to assess the extent of highway damage and determine the priority of highway maintenance appropriately.

\section{CONCLUSION}

Based on the results of research and discussion, the system built is a combination of ANP and web-based methods can be applied in the highway maintenance planning process, with 
the following conclusion that the alternatives ranking can be accessed online so that the decision can be taken quickly and accurately. Based on the accuracy result obtained from the system is $80 \%$ with field data from the Minister of Public Works consisting of six (6) provincial roads and fourteen (14) national road segments. And the real value of each parameter used on each road segment is very influential in the ranking process for priority in highway maintenance.

The results of this study still restricted. It can be expanded by integrating sensors and systems in realtime in particular places for the measurement of the vehicle capacity parameters of the number of vehicles on highway section. This research is also useful for road users, with the maintained road the oxidant will be decreased.

\section{ACKNOWLEDGMENTS}

The author would like to express his sincere thanks to all those who have helped in this research. Particularly to the Office of Public Works-Human Settlements and Spatial Planning of Central Java because it has been willing to be the source of data for this research.

\section{REFERENCES}

[1] Law of the Republic of Indonesia Number 38 Year 2004 Concerning the Highway.

[2] Ibeto, I., and Justine, C., 2012. Issues And Challenges In Local Government Project Monitoring And Evaluation In Nigeria: The Way Forward. European Scientific Journal, Vol. 8, No.18, ISSN: $1857-7881$.

[3] Tanjung, H., and Devi, A., 2013, Metodologi Penelitian Ekonomi Islam, Gramatika, Bekasi.

[4] T.L. Saaty, 2004, Fundamentals Of The Analytic Network Process - Dependence And Feedback In Decision-Making With A Single Network, Journal of systems science and systems engineering, Vol. 13, No. 2, pp129-157.
[5] Regulation of the Minister of Public Works No. 13 of 2011 on Procedures for Maintenance and Highway Ownership.

[6] T.L. Saaty and L.G. Varga, 2006, Decision Making with the Analytic Network Process: Economic, Political, Social and Technological edisi 2, Springer, New York.

[7] Ivanovic, I., Grujicic, D., Macura, D., Jovic, J., Bojovic, N., 2013. One Approach For Road Transport Project Selection. Transport Policy 25 (2013) 22-29.

[8] M.M. Senante, T. Gomez., R. Caballero and H.F Sancho, R.S. Garrido., 2015, Assessment of wastewater treatment alternatives for small communities: An analytic network process approach, Science of The Total Environment 532, $1676-687$.

[9] Cai, S. H., Yao, X. G., and Ping, T., 2007. Evaluation of the Design Alternatives of Emergency Bridge by Applying Analytic Network Process (ANP). Systems Engineering - Theory \& Practice. Volume 27, SETP, 2007, 27(3): 63-70.

[10] Prince, B., Zhen, C., and Stephen, O. O., 2015. An Analytical network process Model For Risks Prioritization In Megaprojects. International Journal of Project Management, (2015) No of Pages 17.

[11] Landicho, J. A., 2017. A Web-Based Geographical Project Monitoring And Information system For The Road And Highways. Journal of Electrical Systems and Information Technology (2017) No of Pages 10.

[12] Kannan, P., Flechas, T., Mendez, E., Angarita, L., and Chaudhari, P., 2016. A web-Based Collection And Analysis Of Process Safety Incidents. Journal of Loss Prevention in the Process Industries 44 (2016) 171-192. 